\title{
The Thermochemistry of Group 15 Tetrachloride Anions
}

\author{
Barry W. Walker, Catherine E. Check, Kim C. Lobring, \\ Cynthia Ann Pommerening, and Lee S. Sunderlin \\ Department of Chemistry and Biochemistry, Northern Illinois University, DeKalb, Illinois, USA
}

\begin{abstract}
Bond strengths for a series of Group 15 tetrachloride anions $\mathrm{ACl}_{4}^{-}(\mathrm{A}=\mathrm{P}, \mathrm{As}, \mathrm{Sb}$, and $\mathrm{Bi})$ have been determined by measuring thresholds for collision-induced dissociation of the anions in a flowing afterglow-tandem mass spectrometer. The central atoms in these systems have ten electrons, which violates the octet rule: the bond dissociation energies for $\mathrm{ACl}_{4}^{-}$help to clarify the effect of the central atom on hypervalent bond strengths. The $0 \mathrm{~K}$ bond energies in $\mathrm{kJ} \mathrm{mol}^{-1}$ are $\mathrm{D}\left(\mathrm{Cl}_{3} \mathrm{~A}-\mathrm{Cl}^{-}\right)=90 \pm 7,115 \pm 7,161 \pm 8$, and $154 \pm 15$, respectively. Computational results using the B3LYP/LANL2DZpd level of theory are higher than the experimental bond energies. Calculations give a geometry for $\mathrm{BiCl}_{4}^{-}$that is essentially tetrahedral rather than the see-saw observed for the other tetrachlorides. NBO calculations predict that the phosphorus and arsenic systems have $3 \mathrm{C}-4 \mathrm{E}$ bonds, while the antimony and bismuth systems are more ionic. (J Am Soc Mass Spectrom 2002, 13, 469-476) @ 2002 American Society for Mass Spectrometry
\end{abstract}

$\tau^{\text {p }}$ roup 15 tetrahalide anions are standard examples of hypervalent bonding [1, 2, 3]. For example, an electron dot structure for $\mathrm{PCl}_{4}^{-}$shows ten electrons around the phosphorus atom, nominally violating the octet rule. Two main competing models have been used to explain how this bonding occurs. One is the expansion of the octet through the use of $\mathrm{d}$ orbitals [4]. The other is the three-center four-electron $(3 \mathrm{C}-4 \mathrm{E})$ model $[1,5,6,7]$, where three $p$ orbitals aligned with a molecular axis are used to form three molecular orbitals. This model is illustrated in Figure 1. Most modern theoretical work suggests that the $3 \mathrm{C}-4 \mathrm{E}$ model is more accurate [8]. Most introductory textbooks, however, still explain hypervalent bonding using the expanded octet model [9]. Additional models that emphasize the ionic character of the bonding have also been proposed [10].

Hypervalent compounds are computational challenges because of the number of electrons involved and strong electron correlation effects [11, 12]. The majority of the computational studies on group 15 halides have focused on bond energies and electron affinities for phosphorus fluorides [13, 14, 15] and phosphorus chlorides [16]. Ab initio calculations on hypervalent group 15 hydrides and fluorides [12, 17, 18], trihalides and pentahalides [19], and a variety of

Published online March 27, 2002

This paper is dedicated to Peter Armentrout in celebration of his winning the 2001 Biemann Medal, and in appreciation of his mentoring and friendship.

Address reprint requests to Dr. Lee Sunderlin, Department of Chemistry and Biochemistry, Northern Illinois University, DeKalb, Illinois 60115, USA. E-mail: sunder@niu.edu phosphorus and arsenic species [20] suggest that $d$ orbital involvement in the bonding is minimal. However, computational work on other hypervalent group 15 halides is lacking.

The work of Peter Armentrout has exemplified the use of systematic measurements of bond strengths and reaction dynamics to clarify periodic trends in bonding [21]. Analysis of periodic trends in the bond strengths in hypervalent compounds can provide insight into the nature of hypervalent bonding. However, solutionphase measurements of bond strengths to halide anions are difficult to interpret because of strong solvation effects [22]. Although some gas-phase measurements of the thermochemistry of group 15 halide anions have been made, previous studies have not been comprehensive. Larson and McMahon [23] measured $\mathrm{D}\left(\mathrm{F}_{3} \mathrm{P}-\mathrm{F}^{-}\right)=$ $168 \mathrm{~kJ} \mathrm{~mol}^{-1}, \mathrm{D}\left(\mathrm{F}_{3} \mathrm{As}-\mathrm{F}^{-}\right)=202 \mathrm{~kJ} \mathrm{~mol}^{-1}, \mathrm{D}\left(\mathrm{F}_{3} \mathrm{P}_{-} \mathrm{Cl}^{-}\right)=$ $65 \mathrm{~kJ} \mathrm{~mol}^{-1}, \mathrm{D}\left(\mathrm{F}_{3} \mathrm{As}-\mathrm{Cl}^{-}\right)=108 \mathrm{~kJ} \mathrm{~mol}^{-1}$, and the strikingly high $\mathrm{D}\left(\mathrm{F}_{5} \mathrm{P}-\mathrm{F}^{-}\right)=356 \pm 42 \mathrm{~kJ} \mathrm{~mol}^{-1}$. Haartz and McDaniel obtained lower limits on the fluoride affinities $\mathrm{D}\left(\mathrm{F}_{5} \mathrm{~A}-\mathrm{F}^{-}\right) \geq 297 \mathrm{~kJ} \mathrm{~mol}^{-1}(\mathrm{~A}=\mathrm{P}$, As) [24]. This study measures the bond dissociation energies for $\mathrm{ACl}_{4}^{-}(\mathrm{A}=\mathrm{P}, \mathrm{As}, \mathrm{Sb}$, and $\mathrm{Bi})$ to clarify the effect of the central atom on hypervalent bond strengths.

Group 15 halides are of practical significance. They are utilized as Friedel-Crafts reagents, oxygen atom abstraction agents, halide transfer reagents, semiconductor dopants, strong Lewis acids, nonaqueous solvents, and electron transfer catalysts $[25,26]$. The hexahalides are among the best noncoordinating anions [27, 28], and are often found as counterions for highly reactive cations [29]. 


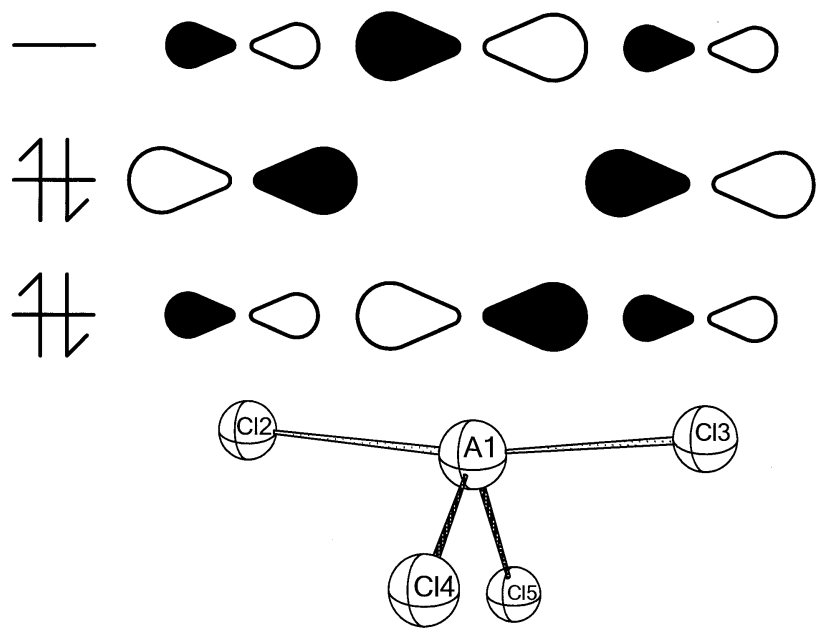

Figure 1. Molecular orbital diagram for hypervalent bonding, aligned with a sketch of $\mathrm{ACl}_{4}^{-}$.

\section{Experimental}

Bond strengths were measured using the energy-resolved collision-induced dissociation (CID) technique developed substantially by Peter Armentrout and coworkers [30, 31] in a flowing afterglow-tandem mass spectrometer (MS) [32]. The instrument consists of an ion source region, a flow tube, and the tandem MS. The DC discharge ion source used in these experiments is typically set at $2000 \mathrm{~V}$ with $2 \mathrm{~mA}$ of emission current. The flow tube is a $92 \mathrm{~cm} \times 7.3 \mathrm{~cm}$ i.d. stainless steel pipe that operates at a buffer gas pressure of 0.4 torr with a flow rate of 200 standard $\mathrm{cm}^{3} \mathrm{~s}^{-1}$. The buffer gas is helium with up to $10 \%$ argon added to stabilize the DC discharge.

To make the ions for this study, the Group 15 trichlorides were added to the ion source. Electron impact on $\mathrm{ACl}_{3}(\mathrm{~A}=\mathrm{P}, \mathrm{As}, \mathrm{Sb}$, and $\mathrm{Bi})$ produces $\mathrm{Cl}^{-}$, which adds to $\mathrm{ACl}_{3}$ to form $\mathrm{ACl}_{4}^{-}$. Approximately $10^{5}$ collisions with the buffer gas cool the metastable $\mathrm{ACl}_{4}^{-}$ ions to room temperature.

For the lighter trichlorides, the flow of the precursor was controlled through a metering valve. A flow of argon over $\mathrm{BiCl}_{3}$ was used to increase the flow rate of the trihalide. $\mathrm{SbCl}_{3}$ and $\mathrm{BiCl}_{3}$ were heated to an estimated 100 and $200{ }^{\circ} \mathrm{C}$, respectively, in a round-bottom flask grooved and wrapped with coils of nichrome heating wire.

The tandem MS includes a quadrupole mass filter, an octopole ion guide, a second quadrupole mass filter, and a detector, contained in a stainless steel box that is partitioned into five interior chambers. Differential pumping on the five chambers ensures that further collisions of the ions with the buffer gas are unlikely after ion extraction. During CID experiments, the ions are extracted from the flow tube and focused into the first quadrupole for mass selection. The reactant ions are then focused into the octopole, which passes through a reaction cell that contains a collision gas. $\mathrm{Ar}$ was used as the collision gas for $\mathrm{PCl}_{4}^{-}$and $\mathrm{AsCl}_{4}^{-}$, and Xe was used for $\mathrm{SbCl}_{4}^{-}$and $\mathrm{BiCl}_{4}^{-}$. Xe is a more effective energy transfer reagent, while the effects of ion beam energy broadening are less in the case of Ar. In experiments on $\mathrm{SbCl}_{4}^{-}$, the two collision gases give indistinguishable thermochemical results. After the dissociated and unreacted ions pass through the reaction cell, the second quadrupole is used for mass analysis. The detector is an electron multiplier operating in pulsecounting mode.

The energy threshold for CID is determined by modeling the cross section for product formation as a function of the reactant ion kinetic energy in the centerof-mass $(\mathrm{CM})$ frame, $\mathrm{E}_{\mathrm{cm}}$ [31]. The octopole is used as a retarding field analyzer to measure the reactant ion beam energy zero. The ion kinetic energy distribution is typically Gaussian with a full-width at half-maximum of $0.5-1.2 \mathrm{eV}\left(1 \mathrm{eV}=96.5 \mathrm{~kJ} \mathrm{~mol}^{-1}\right)$. The octopole offset voltage measured with respect to the center of the Gaussian fit gives the laboratory kinetic energy, $\mathrm{E}_{\mathrm{lab}}$, in $\mathrm{eV}$. Low offset energies are corrected for truncation of the ion beam. To convert to the center-of-mass (CM) frame, the equation $E_{c m}=E_{l a b} m(m+M)^{-1}$ is used, where $\mathrm{m}$ and $\mathrm{M}$ are the masses of the neutral and ionic reactants, respectively. All experiments were performed with both mass filters at low resolution to improve ion collection efficiency and reduce mass discrimination. Average masses were used for $\mathrm{Cl}, \mathrm{Sb}$, and $\mathrm{Xe}$, which have substantial populations of two or more isotopes.

The total cross section for a reaction, $\sigma_{\text {total }}$, is calculated using equation 1 , where $\mathrm{I}$ is the intensity of the reactant ion beam, $\mathrm{I}_{\mathrm{O}}$ is the intensity of the incoming beam $\left(\mathrm{I}_{\mathrm{o}}=\mathrm{I}+\sum \mathrm{I}_{\mathrm{i}}\right), \mathrm{I}_{\mathrm{i}}$ is the intensity of each product ion, $\mathrm{n}$ is the number density of the collision gas, and $l$ is the effective collision length, $13 \pm 2 \mathrm{~cm}$. Individual product cross sections $\sigma_{\mathrm{i}}$ are equal to $\sigma_{\text {total }}\left(\mathrm{I}_{\mathrm{i}} / \Sigma \mathrm{I}_{\mathrm{i}}\right)$.

$$
\mathrm{I}=\mathrm{I}_{\mathrm{o}} \exp \left(-\sigma_{\text {total }} \mathrm{n} l\right)
$$

Threshold energies are derived by fitting the data to a model function given in equation 2, where $\sigma(\mathrm{E})$ is the cross section for formation of the product ion at centerof-mass energy $\mathrm{E}, \mathrm{E}_{\mathrm{T}}$ is the desired threshold energy, $\sigma_{\mathrm{o}}$ is the scaling factor, $n$ is an adjustable parameter, and $i$ denotes rovibrational states having energy $E_{\mathrm{i}}$ and population $\mathrm{g}_{\mathrm{i}}\left(\Sigma \mathrm{g}_{\mathrm{i}}=1\right)$. Doppler broadening and the kinetic energy distribution of the reactant ion are also accounted for in the data analysis, which is done using the $\mathrm{CRUNCH}$ program written by P. B. Armentrout and coworkers [31].

$$
\sigma(\mathrm{E})=\sigma_{\mathrm{o}} \sum_{\mathrm{i}} \mathrm{g}_{\mathrm{i}}\left(\mathrm{E}+\mathrm{E}_{\mathrm{i}}-\mathrm{E}_{\mathrm{T}}\right)^{\mathrm{n}} / \mathrm{E}
$$

Although the $\mathrm{ACl}_{3}$ vibrational frequencies [33] and some of the $\mathrm{ACl}_{4}^{-}$vibrational frequencies $[33,34]$ are known, the available data is not complete, and condensed-phase intermolecular interactions may affect the available data. Therefore, vibrational and rotational frequencies for gas-phase $\mathrm{ACl}_{4}^{-}$and $\mathrm{ACl}_{3}(\mathrm{~A}=\mathrm{P}, \mathrm{As}$, and $\mathrm{Sb}$ ) were calculated using the B3LYP method and the LANL2DZpd basis set, which supplements the 
Table 1. Rotational and vibrational constants for Group 15 chlorides

\begin{tabular}{|c|c|c|c|}
\hline Compound & $\begin{array}{l}\text { Vibrational Frequencies } \\
\text { in } \mathrm{cm}^{-1}\end{array}$ & $\begin{array}{l}\text { Rotational Constants } \\
\text { in } \mathrm{cm}^{-1}\end{array}$ & Polarizabilities in $\AA^{3}$ \\
\hline $\mathrm{PCl}_{3}$ exp. $^{\mathrm{a}}$ & $186 \times 2,258,504 \times 2,515$ & & \\
\hline $\mathrm{PCl}_{3}$ calc $^{\mathrm{b}}$ & $174 \times 2,241,471 \times 2,495$ & $0.0822(x 2), 0.0461$ & 8.105 \\
\hline $\mathrm{PCl}_{4}^{-}{ }^{-} \mathrm{calc}^{\mathrm{b}}$ & $\begin{array}{l}88.8,115,148,157,197 \\
213,280,431,460\end{array}$ & $0.0593,0.0330, .0280$ & \\
\hline $\mathrm{AsCl}_{3}$ exp. $^{\mathrm{a}}$ & $150 \times 2,193,391 \times 2,417$ & & \\
\hline $\mathrm{AsCl}_{3} \mathrm{calc}^{\mathrm{b}}$ & $143 \times 2,184,369 \times 2,399$ & $0.0683(x 2), 0.0424$ & 8.770 \\
\hline $\mathrm{AsCl}_{4}^{-} \mathrm{calc}^{\mathrm{b}}$ & $\begin{array}{l}73.2,86.4,127,143 \\
154,217,226,332,360\end{array}$ & $\begin{array}{l}0.0520,0.0303, \\
0.0263\end{array}$ & \\
\hline $\mathrm{SbCl}_{3}$ exp. $^{\mathrm{a}}$ & $122 \times 2,151,359 \times 2,381$ & & \\
\hline $\mathrm{SbCl}_{3} \mathrm{calc}^{\mathrm{b}}$ & $112 \times 2,140,334 \times 2,356$ & $0.0555(x 2), 0.0372$ & 10.094 \\
\hline $\mathrm{SbCl}_{4}^{-}$calc $^{\mathrm{b}}$ & $\begin{array}{l}59.4,67.7,110,121, \\
125,220,220,297,319\end{array}$ & $\begin{array}{l}0.0448,0.0270 \\
0.0234\end{array}$ & \\
\hline $\mathrm{BiCl}_{3}$ exp. $^{\mathrm{a}}$ & $107 \times 2,123,322 \times 2,342$ & & \\
\hline $\mathrm{BiCl}_{3}$ calc $^{\mathrm{b}}$ & $\begin{array}{l}99.5 \times 2,116,308 \times 2, \\
332\end{array}$ & $0.0497(x 2), 0.0345$ & 10.541 \\
\hline $\mathrm{BiCl}_{4}^{-} \mathrm{calc}^{\mathrm{b}}$ & $\begin{array}{l}28.7,28.7,31.6,61.2 \\
63.1,231,231,231,269\end{array}$ & $\begin{array}{l}0.0263,0.0262, \\
0.0262\end{array}$ & \\
\hline
\end{tabular}

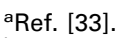

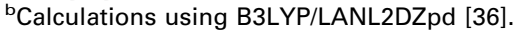

relativistic effective core potential and double-zeta valence basis set of LANL2DZ [35] with additional polarization and diffuse functions [36]. The frequencies are given in Table 1. The calculated frequencies are lower than the experimental values for $\mathrm{ACl}_{3}$ by $3-8 \%$. Uncertainties in the derived thresholds due to possible inaccuracies in the frequencies were estimated by multiplying the entire sets of frequencies by 0.9 and 1.1. The resulting changes in internal energies were less than 1 $\mathrm{kJ} \mathrm{mol}{ }^{-1}$. Therefore, the calculated frequencies were used without scaling. Polarizabilities for neutral molecules were also taken from the computational results.

Collisionally activated metastable complexes can have sufficiently long lifetimes that they do not dissociate on the experimental timescale (ca. $30 \mu \mathrm{s}$ ). Such kinetic shifts are accounted for in the CRUNCH program by RRKM lifetime calculations [31]. The kinetic shifts depend on calculated densities of states for the activated ion and the dissociation transition state. The dissociation is taken to have a loose, product-like transition state [30, 31]. The relatively small molecules studied in this work are calculated to have small kinetic shifts, less than $4 \mathrm{~kJ} / \mathrm{mol}$. The uncertainty in the density of states is again estimated by multiplying reactant or product frequency sets by 0.9 and 1.1, and by multiplying the time window for dissociation by 10 and 0.1 . The effect ranges from less than $1 \mathrm{~kJ} \mathrm{~mol}^{-1}$ for $\mathrm{PCl}_{4}^{-}$to 3 $\mathrm{kJ} / \mathrm{mol}$ for $\mathrm{BiCl}_{4}^{-}$.

An ion not sufficiently energized by one collision with the target gas may gain enough energy in a second collision to be above the dissociation threshold. This effect is eliminated by linear extrapolation of the data taken at several pressures to a zero pressure cross section before fitting the data [37].

Computational work on these systems was performed using the Gaussian 98 Suite [38]. Basis set superposition error was determined by counterpoise calculations to be minor $(<4 \mathrm{~kJ} / \mathrm{mol})$ in these systems. The Natural Bond Order Analysis (NBO 5.0) [39] and Atoms In Molecules (AIM) [40, 41, 42] programs were also used to study the nature of the bonding in these systems. Because the AIM calculations as implemented in G98W are not compatible with effective core potentials, the calculations were done using the B3LYP method and the $3-21 \mathrm{G}^{*}$ basis set supplemented with diffuse functions taken from the LANL2DZpd basis set [36]. No AIM calculations on the bismuth systems were done because of the lack of an appropriate basis set. Where direct comparisons are available, the LANL2DZpd and augmented 3-21G* basis sets give similar geometries, NBO atomic charges, and other parameters.

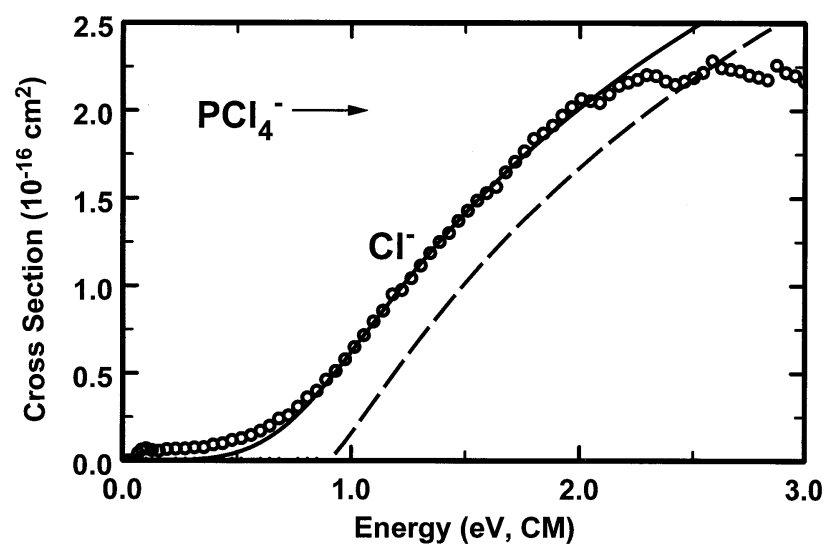

Figure 2. Cross section for collision-induced dissociation of $\mathrm{PCl}_{4}^{-}$ as a function of energy in the center-of-mass frame. The solid and dashed lines represent convoluted and unconvoluted fits to the data, as discussed in the text. 


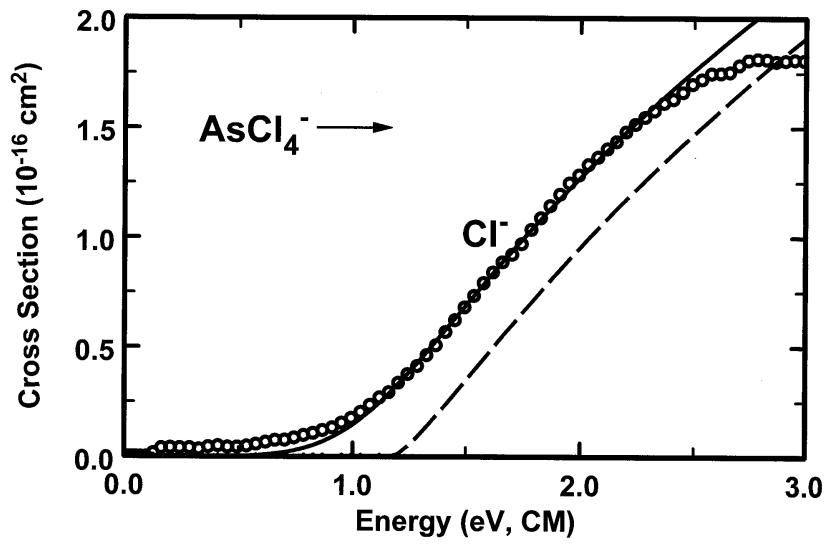

Figure 3. Cross section for collision-induced dissociation of $\mathrm{AsCl}_{4}^{-}$as a function of energy in the center-of-mass frame. The solid and dashed lines represent convoluted and unconvoluted fits to the data, as discussed in the text

\section{Results}

CID of $\mathrm{ACl}_{4}^{-}$gives loss of $\mathrm{Cl}^{-}$, Reaction 3, as the predominant product in all cases. Reactions 4 and 5 are also observed for all four reactant ions. Trace amounts of Reactions 6 and 7 were observed for $\mathrm{A}=\mathrm{Sb}$ and $\mathrm{Bi}$. The neutral products for these reactions are assumed on thermodynamic grounds to be those listed. Appearance curves for CID of the group 15 tetrachloride anions are shown in Figures 2-5. Only the largest secondary product (reaction 4 for $\mathrm{A}=\mathrm{Bi}$ ) is shown; the other products all had cross sections less than $1 \%$ of that for reaction 3 over the energy ranges shown.

$$
\begin{aligned}
& \mathrm{ACl}_{4}^{-} \rightarrow \mathrm{ACl}_{3}+\mathrm{Cl}^{-} \\
& \mathrm{ACl}_{4}^{-} \rightarrow \mathrm{ACl}_{3}^{-}+\mathrm{Cl} \\
& \mathrm{ACl}_{4}^{-} \rightarrow \mathrm{ACl}_{2}+\mathrm{Cl}_{2}^{-} \\
& \mathrm{ACl}_{4}^{-} \rightarrow \mathrm{ACl}_{2}^{-}+\mathrm{Cl}_{2}
\end{aligned}
$$

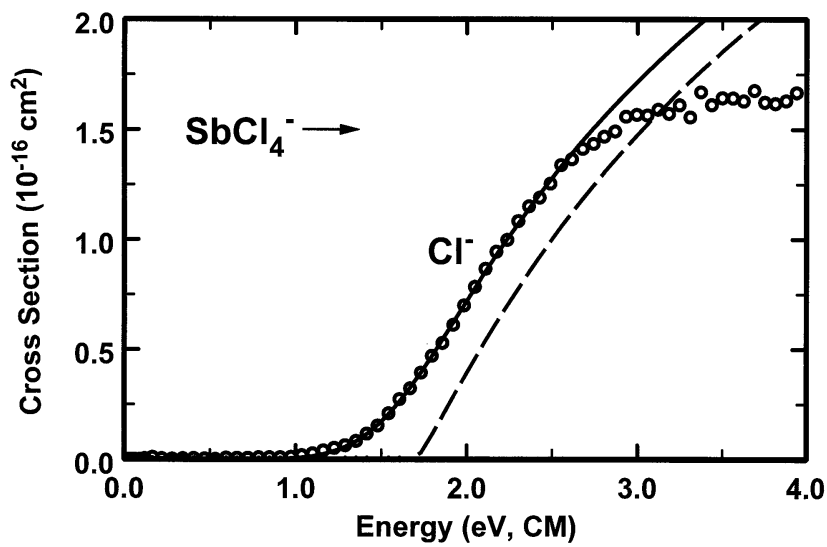

Figure 4. Cross section for collision-induced dissociation of $\mathrm{SbCl}_{4}^{-}$as a function of energy in the center-of-mass frame. The solid and dashed lines represent convoluted and unconvoluted fits to the data, as discussed in the text.

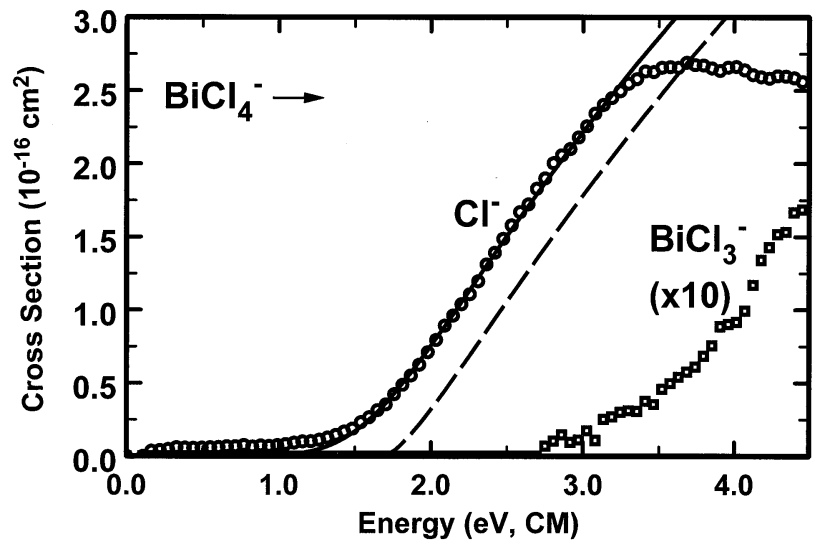

Figure 5. Cross section for collision-induced dissociation of $\mathrm{BiCl}_{4}^{-}$as a function of energy in the center-of-mass frame. The solid and dashed lines represent convoluted and unconvoluted fits to the data for formation of $\mathrm{Cl}^{-}$, as discussed in the text.

$$
\mathrm{ACl}_{4}^{-} \rightarrow \mathrm{ACl}^{-}+\mathrm{Cl}_{2}+\mathrm{Cl}
$$

The equation 2 fitting parameters are given in Table 2 , and the fits are shown in Figures $2-5$ as well. The cross sections for minor products are negligible in the threshold region, and are not included in the fit. The dissociation thresholds correspond to bond energies at $0 \mathrm{~K}$, since the effects of reactant and product internal energy are included in the fitting procedure. The final uncertainties in the bond energies are derived from the standard deviation of the thresholds determined for individual data sets, the uncertainty in the reactant internal energy, the effects of kinetic shifts, and the uncertainty in the energy scale $( \pm 0.15 \mathrm{eV} \mathrm{lab})$. These results are given in Table 3.

The $0 \mathrm{~K}$ bond energies can be converted into $298 \mathrm{~K}$ bond enthalpies using the heat capacities of the reactants and products. The heat capacities are determined using the frequencies calculated at the B3LYP/ LANL2DZpd level, Table 1. These give $298 \mathrm{~K}$ bond enthalpies that are essentially identical to the $0 \mathrm{~K}$ values, Table 3 . The uncertainty in the heat capacities can be estimated by multiplying the reactant and product frequency sets by 0.9 and 1.1, and has a negligible effect on the final uncertainties.

\section{Discussion}

Periodic trends moving down the periodic table.

As shown in Table 3, the data show a trend of increasing $\mathrm{Cl}_{3} \mathrm{~A}-\mathrm{Cl}^{-}$bond strengths from $\mathrm{A}=\mathrm{P}$ to $\mathrm{A}=\mathrm{Sb}$,

Table 2. Fitting parameters for CID of $\mathrm{ACl}_{4}{ }^{-}$anions ${ }^{\mathrm{a}}$

\begin{tabular}{lccc}
\hline $\mathrm{A}$ & $\mathrm{E}_{\mathrm{T}}(\mathrm{eV})$ & $n$ & $\sigma_{0}$ \\
\hline \hline $\mathrm{P}$ & $0.93 \pm 0.06$ & $1.23 \pm 0.05$ & $3.5 \pm 0.9$ \\
$\mathrm{As}$ & $1.20 \pm 0.07$ & $1.38 \pm 0.14$ & $2.7 \pm 0.9$ \\
$\mathrm{Sb}$ & $1.67 \pm 0.10$ & $1.16 \pm 0.13$ & $4.5 \pm 1.9$ \\
$\mathrm{Bi}$ & $1.60 \pm 0.16$ & $1.45 \pm 0.18$ & $3.9 \pm 2.1$
\end{tabular}

aSee text for discussion of fitting parameters. 
Table 3. Bond dissociation enthalpies for $\mathrm{ACl}_{4}{ }^{-}$anions ${ }^{\mathrm{a}}$

\begin{tabular}{lccc}
\hline A & $0 \mathrm{~K}$ & $298 \mathrm{~K}$ & Theo. $(0 \mathrm{~K})^{\mathrm{b}}$ \\
\hline \hline $\mathrm{P}$ & $90 \pm 7$ & $90 \pm 7$ & 108.4 \\
$\mathrm{As}$ & $115 \pm 7$ & $115 \pm 7$ & 139.1 \\
$\mathrm{Sb}$ & $161 \pm 8$ & $160 \pm 8$ & 173.2 \\
$\mathrm{Bi}$ & $154 \pm 15$ & $153 \pm 15$ & 207.6 \\
\hline
\end{tabular}

avalues in $\mathrm{kJ} \mathrm{mol}^{-1}$

${ }^{b}$ Calculated using B3LYP/LANL2DZpd [36].

with the bismuth bond strength similar to that for antimony. Similar trends are seen in the calculated hydride and fluoride affinities [12, 18]. Two experimental bond energies in fluoride systems, $\mathrm{D}\left(\mathrm{F}_{3} \mathrm{P}-\mathrm{F}^{-}\right)=168$ $\mathrm{kJ} \mathrm{mol}^{-1}$ and $\mathrm{D}\left(\mathrm{F}_{3} \mathrm{As}-\mathrm{F}^{-}\right)=202 \mathrm{~kJ} \mathrm{~mol}^{-1}$ [23], also follow a similar trend to that seen in the present data: the ratio of the fluoride bond strengths for arsenic and phosphorus is 1.20 , and the ratio of the chloride bond strengths is 1.28. This trend contrasts with the average of the $298 \mathrm{~K}$ neutral bond enthalpies: $\mathrm{DH}(\mathrm{A}-3 \mathrm{Cl}) / 3=$ $316,306,311$, and $289 \mathrm{~kJ} / \mathrm{mol}$ for $\mathrm{A}=\mathrm{P}, \mathrm{As}, \mathrm{Sb}$, and $\mathrm{Bi}$ [43].

Important computed bond lengths and angles are given in Table 4. The $\mathrm{ACl}_{4}^{-}$molecules are all calculated to have $\mathrm{C}_{2 v}$ symmetry, while the $\mathrm{ACl}_{3}$ molecules are $\mathrm{C}_{3 v}$. The average bond lengths are longer for central atoms lower in the periodic table. The difference between the axial $\left(R_{12}\right.$ and $\left.R_{13}\right)$ and equatorial $\left(R_{14}\right.$ and $\mathrm{R}_{15}$ ) A-Cl bond lengths gets smaller for heavier central atoms, and calculations give a geometry for $\mathrm{BiCl}_{4}^{-}$that is essentially tetrahedral (with four nearly equal $\mathrm{Bi}-\mathrm{Cl}$ bond lengths) rather than a see-saw.

The maximum cross sections for $\mathrm{A}=\mathrm{P}$ to $\mathrm{Bi}$ are 2.2, $1.8,1.7$, and $2.6 \AA^{2}$, respectively. There is a general trend of smaller cross sections for molecules with stronger bonds. Additionally, there is a smaller cross section for $\mathrm{CID}$ with $\mathrm{Ar}(\mathrm{A}=\mathrm{P}$ and $\mathrm{As})$ than with $\mathrm{Xe}(\mathrm{A}=\mathrm{Sb}$ and $\mathrm{Bi}$ ). The size of the anion (largest for $\mathrm{A}=\mathrm{Bi}$ ) may also have an influence on the observed cross sections.

These trends can be compared with results from the AIM and NBO calculations discussed in the experimental section. The atomic charges calculated with these methods are given in Table 5. Both models indicate that the central atoms are positively charged, and become more so for atoms lower on the periodic table. Addition of $\mathrm{Cl}^{-}$to $\mathrm{ACl}_{3}$ has a negligible effect (less than 0.1 electron) on the charge of the central atom. Although

Table 4. Structural properties of $\mathrm{ACl}_{4}{ }^{-}$and $\mathrm{ACl}_{3}{ }^{\mathrm{a}}$

\begin{tabular}{lrrrrrrr}
\hline & \multicolumn{4}{c}{$\mathrm{ACl}_{4}^{-}$} & & \multicolumn{2}{c}{$\mathrm{ACl}_{3}$} \\
\cline { 2 - 4 } $\mathrm{A}$ & $\mathrm{R}_{12}$ & $\mathrm{R}_{14}$ & $L_{213}$ & $L_{214}$ & & $\mathrm{R}_{\mathrm{ACl}}$ & $\angle_{\text {CIACI }}$ \\
\hline \hline $\mathrm{P}$ & 2.44 & 2.14 & 170.6 & 93.0 & & 2.10 & 100.4 \\
$\mathrm{As}$ & 2.51 & 2.26 & 169.9 & 93.3 & & 2.21 & 99.4 \\
$\mathrm{Sb}$ & 2.63 & 2.44 & 174.6 & 91.7 & & 2.39 & 98.0 \\
$\mathrm{Bi}$ & 2.62 & 2.62 & 109.4 & 109.5 & & 2.45 & 99.2 \\
\hline
\end{tabular}

aBond distances in Angstroms and angles in degrees calculated using B3LYP/LANL2DZpd [36]. For atom labels refer to Figure 1.
Table 5. Calculated atomic charges ${ }^{\mathrm{a}}$

\begin{tabular}{llllllll}
\hline & & \multicolumn{3}{c}{$\mathrm{ACl}_{4}{ }^{-}$} & & \multicolumn{2}{c}{$\mathrm{ACl}_{3}$} \\
\cline { 3 - 5 } \cline { 7 - 8 } Technique & $\mathrm{A}$ & $\mathrm{q}_{\mathrm{A}}$ & $\mathrm{q}_{\mathrm{CI}}(\mathrm{ax})$ & $\mathrm{q}_{\mathrm{CI}}(\mathrm{eq})$ & & $\mathrm{q}_{\mathrm{A}}$ & $\mathrm{q}_{\mathrm{Cl}}$ \\
\hline \hline AIM & $\mathrm{P}$ & 1.08 & -0.61 & -0.42 & & 1.17 & $1-0.39$ \\
& $\mathrm{As}$ & 1.24 & -0.64 & -0.49 & & 1.27 & -0.42 \\
\multirow{4}{*}{ NBO } & $\mathrm{Sb}$ & 1.47 & -0.68 & $-0.56-$ & & 1.46 & -0.49 \\
& $\mathrm{P}$ & 0.77 & -0.56 & -0.32 & & 0.80 & -0.27 \\
& $\mathrm{As}$ & 0.97 & -0.59 & -0.40 & & 1.01 & -0.34 \\
& $\mathrm{Sb}$ & 1.31 & -0.65 & -0.51 & & 1.35 & -0.45 \\
& $\mathrm{LBi}$ & 1.47 & -0.62 & -0.62 & & 1.43 & -0.48 \\
\hline
\end{tabular}

${ }^{a}$ See text for discussion of model and basis set choices.

the axial chlorides bear formal charges of -0.5 in the $3 \mathrm{C}-4 \mathrm{E}$ model, the axial chlorides in $\mathrm{PCl}_{4}^{-}$are more negatively charged than the equatorial chlorides by only 0.24 electrons, and the difference drops to zero for bismuth. This indicates that $\mathrm{A}-\mathrm{Cl}$ bond polarization is a more important factor than the formal oxidation state on the atomic charges, and that the bonding becomes more ionic for heavier central atoms.

The AIM calculations indicate that the longer axial $\mathrm{A}-\mathrm{Cl}$ bonds have a lower bond order than the equatorial bonds, Table 6 . The equatorial and axial bond orders are in good agreement with the respective values of one and $1 / \sqrt{ } 2(0.71)$ predicted using the $3 \mathrm{C}-4 \mathrm{E}$ model [44]. However, neither the axial bond orders nor the sum of all the bond orders correlate with the trend in the experimental bond strengths.

The NBO (Natural Population Analysis) calculations show differences between the bonding in the $\mathrm{ACl}_{4}^{-}$ systems. While the phosphorus and arsenic systems are computed to have $3 \mathrm{C}-4 \mathrm{E}$ bonds, the antimony and bismuth systems are calculated to have structures that are better considered as +3 ions surrounded by four chloride anions. All four species, no doubt, lie on the continuum between the covalent 3C-4E description and a purely ionic description, with the heavier atoms giving more ionic bonding [10]. The lone pair of electrons in $\mathrm{BiCl}_{4}^{-}$is in a nearly pure $6 \mathrm{~s}$ orbital, while for the other species studied, there is some $\mathrm{p}$ character to the orbital. This is consistent with the geometry calculated for $\mathrm{BiCl}_{4}^{-}$(tetrahedral) but not the other $\mathrm{ACl}_{4}^{-}$molecules (see-saw) or any of the $\mathrm{ACl}_{3}$ molecules (pyramidal). The tendency of bismuth to have a stereochemically inactive lone pair of electrons in the s orbital, which can be attributed to greater relativistic stabilization of electrons in lower angular momentum orbitals on heavy atoms (the inert pair effect), has been previously discussed [3].

Table 6. AIM bond orders ${ }^{\mathrm{a}}$

\begin{tabular}{lccc}
\hline $\mathrm{A}$ & $\mathrm{BO}\left(\mathrm{ACl}_{4}{ }^{-}, \mathrm{ax}\right)$ & $\mathrm{BO}\left(\mathrm{ACl}_{4}{ }^{-}, \mathrm{eq}\right)$ & $\mathrm{BO}\left(\mathrm{ACl}_{3}\right)$ \\
\hline \hline $\mathrm{P}$ & 0.75 & 1.05 & 1.10 \\
$\mathrm{As}$ & 0.76 & 0.98 & 1.07 \\
$\mathrm{Sb}$ & 0.72 & 0.88 & 0.99 \\
\hline
\end{tabular}

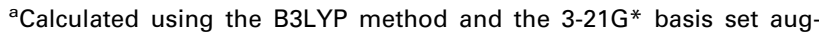
mented with additional diffuse functions as discussed in the text. 
The NBO calculations also give total valence $\mathrm{d}$ orbital occupancies of 0.07 electrons or less in all $\mathrm{ACl}_{3}$ and $\mathrm{ACl}_{4}^{-}$systems, and the occupancy in $\mathrm{ACl}_{3}$ is greater than or equal to the occupancy in $\mathrm{ACl}_{4}^{-}$for any central element $\mathrm{A}$. This supports the idea that $\mathrm{d}$ orbitals on the central atom do not participate significantly in the bonding molecular orbitals of the molecule.

\section{Periodic trends moving across the periodic table.}

The bond energies in $\mathrm{SiCl}_{5}^{-}, \mathrm{PCl}_{4}^{-}, \mathrm{SCl}_{3}^{-}$, and $\mathrm{ClCl}_{2}^{-}$are $101 \pm 8$ [23], $90 \pm 7,85 \pm 8$ [45], and $99 \pm 5 \mathrm{~kJ} / \mathrm{mol}[11]$, respectively. All of these values are equal within their combined uncertainties. This indicates that the bond energy does not change significantly as the central atom is changed across the periodic table, maintaining the same ten-electron count on the central atom.

\section{Comparison to previous studies.}

Trinquier et al. [20] calculated $\mathrm{D}\left(\mathrm{Cl}_{3} \mathrm{P}_{-} \mathrm{Cl}^{-}\right)=79 \mathrm{~kJ}$ $\mathrm{mol}^{-1}$ using a relatively small basis set and no electron correlation. Gutsev [16] obtained a value of $129 \mathrm{~kJ} \mathrm{~mol}^{-}$ using comparatively sophisticated density functional calculations. $0 \mathrm{~K}$ bond energies calculated at the B3LYP/LANL2DZpd level, given in Table 3, are higher than the experimental bond energies for $\mathrm{A}=\mathrm{P}, \mathrm{As}$, and $\mathrm{Sb}$ by $12-24 \mathrm{~kJ} / \mathrm{mol}$. This is similar to the computational overestimate seen for the trihalide anions [36]. The values for bismuth differ by $54 \mathrm{~kJ} / \mathrm{mol}$, suggesting that the B3LYP/LANL2DZpd method is not reliable for the energetics of bismuth compounds. However, the agreement with the experimental frequencies for $\mathrm{BiCl}_{3}$ suggest that other properties may be accurate.

Larson and McMahon [23] measured $\mathrm{DH}\left(\mathrm{F}_{3} \mathrm{P}-\mathrm{Cl}^{-}\right)=$ $65 \mathrm{~kJ} \mathrm{~mol}^{-1}$ and $\mathrm{DH}\left(\mathrm{F}_{3} \mathrm{As}^{-} \mathrm{Cl}^{-}\right)=108 \mathrm{~kJ} \mathrm{~mol}^{-1}$. These are close to the $298 \mathrm{~K}$ values measured in this work, $\mathrm{DH}\left(\mathrm{Cl}_{3} \mathrm{P}-\mathrm{Cl}^{-}\right)=84 \mathrm{~kJ} \mathrm{~mol}^{-1}$ and $\mathrm{DH}\left(\mathrm{Cl}_{3} \mathrm{As}_{-} \mathrm{Cl}^{-}\right)=109$ $\mathrm{kJ} \mathrm{mol}^{-}$. This indicates that the nature of the remaining halide ligands does not significantly affect the strength of the bond being broken. Similar results are seen in another hypervalent system: $\mathrm{D}\left(\mathrm{F}_{4} \mathrm{Si}-\mathrm{Cl}^{-}\right)=98 \mathrm{~kJ} \mathrm{~mol}^{-1}$ and $\mathrm{D}\left(\mathrm{Cl}_{4} \mathrm{Si}_{-} \mathrm{Cl}^{-}\right)=101 \mathrm{~kJ} \mathrm{~mol}^{-1}$ [23]. Work is in progress in this laboratory to explore the effect of charge distributions on bond strengths in hypervalent compounds in more detail.

\section{Acknowledgments}

This work was funded by the National Science Foundation, Grant CHE-9985883. We thank Peter Armentrout, Mary Rodgers, and Kent Ervin for use of the CRUNCH software for data analysis, Thomas Gilbert and the NIU Computational Chemistry Laboratory for assistance with the computational work, Doug Fox at Gaussian, Inc. for assistance with the counterpoise calculations, and W. Roy Mason for chemical insight.

\section{References}

1. Reed, A. E.; Schleyer, P. v. R. Chemical Bonding in Hypervalent Molecules. The Dominance of Ionic Bonding and Negative Hyperconjugation Over $\delta$-Orbital Participation. J. Am. Chem. Soc. 1990, 112, 1434-1445.

2. Norman, N. C. Periodicity and the P-block Elements. Oxford University Press: Oxford, 1994.

3. Magnusson, E. Hypercoordinate Molecules of Second-Row Elements: d Functions or d Orbitals? J. Am. Chem. Soc. 1990, 112, 7940-7951.

4. Schaefer, H. F., Ed. Modern Theoretical Chemistry, Vol. 3. Plenum: New York, 1977.

5. Hach, R. J.; Rundle, R. E. The Structure of Tetramethylammonium Pentaiodide. J. Am. Chem. Soc. 1951, 73, 4321-4324.

6. Pimentel, G. C. The Bonding of Trihalide and Bifluoride Ions by the Molecular Orbital Method. J. Chem. Phys. 1951, 19, 446-448.

7. Kaupp, M.; van Wüllen, Ch.; Franke, R.; Schmitz, F.; Kutzelnigg, W. The Structure of $\mathrm{XeF}_{6}$ and of Compounds Isoelectronic with It. A Challenge to Computational Chemistry and to the Qualitative Theory of the Chemical Bond. J. Am. Chem. Soc. 1996, 118, 11939-11950.

8. (a) Heard, G. L.; Marsden, C. J.; Scuseria, G. E. The Trifluoride Anion: A Difficult Challenge for Quantum Chemistry. J. Phys. Chem. 1992, 96, 4359-4366. (b) Novoa, J. J. ; Mota, F.; Alvarez, S. Structure and Stability of the $\mathrm{X}_{3}$ Systems $(\mathrm{X}=\mathrm{F}, \mathrm{Cl}, \mathrm{Br}, \mathrm{I})$ and Their Interaction with Cations. J. Phys. Chem. 1988, 92, 6561-6566. (c) Landrum, G. A.; Goldberg, N.; Hoffmann, R. Bonding in the Trihalides $\left(\mathrm{X}_{3}^{-}\right)$, Mixed Trihalides $\left(\mathrm{X}_{2} \mathrm{Y}^{-}\right)$and Hydrogen Bihalides $\left(\mathrm{X}_{2} \mathrm{H}^{-}\right)$. The Connection Between Hypervalent, Electron-rich Three-Center, Donor-Acceptor and Strong Hydrogen Bonding. J. Chem. Soc., Dalton Trans. 1997, 3605-3613. (d) Gutsev, G. L. Structure and Stability of Trihalogens and Their Anions. Russ. J. Phys. Chem. 1992, 66, 15961599. (e) Cahill, P. A.; Dykstra, C. E.; Martin, J. C. The Structure and the Stability of the 10-F-2 Trifluoride Ion, a Compound of a Hypervalent First Row Element. J. Am. Chem. Soc. 1985, 107, 6359-6362.

9. (a) Atkins, P. W.; Jones, L. L. Chemistry: Molecules, Matter and Change; 3rd ed. W. H. Freeman: New York, 1997. (b) Chang, R. Chemistry; 6th ed. McGraw-Hill: Boston, 1998. (c) McMurry, J.; Fay, R. C. Chemistry; 2nd ed. Prentice-Hall: Upper Saddle River, NJ, 1998. (d) Ebbing, D. D.; Gammon, S. D. General Chemistry; 6th ed. Houghton Mifflin: Boston, 1999. (e) Silverberg, M. Chemistry; 2nd ed. McGraw-Hill: Boston, 2000. (f) Brown, T. L.; LeMay, H. E.; Bursten, B. E. Chemistry: The Central Science; 8th ed. Prentice Hall: Upper Saddle River, NJ, 2000. (g) Brady, J. E.; Russell, J. W.; Holum, J. R. Chemistry: Matter and Its Changes; 3rd ed. Wiley: New York, 2000. (h) Zumdahl, S. S.; Zumdahl, S. A. Chemistry; 5th ed. Houghton Mifflin: Boston, 2000.

10. (a) Häser, M. Characterization of Electronic Structure in Molecules by One-Center Expansion Techniques. No Three-Center Four-Electron Bond in $\mathrm{PF}_{5}$. J. Am. Chem. Soc. 1996, 118, 7311-7325. (b) Cioslowski, J.; Mixon, S. T. Rigorous Interpretation of Electronic Wave Functions. 2. Electronic Structures of Selected Phosphorus, Sulfur, and Chlorine Fluorides and Oxides. Inorg. Chem. 1993, 32, 3209-3216.

11. Nizzi, K. E.; Pommerening, C. A.; Sunderlin, L. S. Gas-Phase Thermochemistry of Polyhalide Anions. J. Phys. Chem. A 1998, $102,7674-7679$.

12. Moc, J.; Morokuma, K. Ab Initio MO Study on the Periodic Trends in Structures and Energies of Hypervalent Compounds: Four-Coordinated $\mathrm{XH}_{4}^{-}$and $\mathrm{XF}_{4}^{-}$Anions Containing a Group 15 Central Atom ( $\mathrm{X}=\mathrm{P}, \mathrm{As}, \mathrm{Sb}, \mathrm{Bi})$. Inorg. Chem. 1994, $33,551-560$. 
13. Gutsev, G. L. A Theoretical Study on the Structure and Stability of the $\mathrm{PF}_{\mathrm{n}}$ and $\mathrm{PF}_{\mathrm{n}}^{-}$Series, $\mathrm{n}=1-6$. J. Chem. Phys. 1993, 98, 444-452.

14. Tschumper, G. S.; Fermann, J. T.; Schaefer, H. F., III. Structure, Thermochemistry, and Electron Affinities of the $\mathrm{PF}_{\mathrm{n}}$ and $\mathrm{PF}_{\mathrm{n}}^{-}$ Series, $\mathrm{n}=1-6$. J. Chem. Phys. 1996, 104, 3676-3683.

15. Gu, J.; Chen, K.; Xie, Y.; Schaefer, H. F., III; Morris, R. A.; Viggiano, A. A. The Electron Affinities of PF and PF2. J. Chem. Phys. 1998, 108, 1050-1054.

16. Gutsev, G. L. A Theoretical Study on the Structure and Stability of the $\mathrm{PCl}_{\mathrm{n}}$ and $\mathrm{PCl}_{\mathrm{n}}^{-}$Series, $\mathrm{n}=1-6$. Chem. Phys. 1994, 179, 325-339.

17. Moc, J.; Morokuma, K. Ab Initio Molecular Orbital Study on the Periodic Trends in Structures and Energies of Hypervalent Compounds: Five-Coordinated $\mathrm{XH}_{5}$ Species Containing a Group 15 Central Atom (X = P, As, Sb, and Bi). J. Am. Chem. Soc. 1995, 117, 11790-11797.

18. Moc, J.; Morokuma, K. Ab Initio MO Study on the Periodic Trends in Structures and Energies of Hypervalent Compounds: Five-, Six-, and Seven-Coordinated $\mathrm{XF}_{5}, \mathrm{XH}_{6}^{-}, \mathrm{XF}_{6}^{-}$, $\mathrm{XH}_{7}^{2-}$ and $\mathrm{XF}_{7}^{2-}$ Species Containing a Group 15 Central Atom (where X is P, As, Sb, Bi). J. Mol. Struct. 1997, 436-437, 401-418.

19. Briedung, J.; Thiel, W. A Systematic Ab Initio Study of the Group V Trihalides $\mathrm{MX}_{3}$ and Pentahalides $\mathrm{MX}_{5}(\mathrm{M}=\mathrm{P}-\mathrm{Bi}$, $\mathrm{X}=\mathrm{F}$ - I). J. Comp. Chem. 1992, 13, 165-176.

20. Trinquier, G.; Daudey, J.; Caruana, G.; Madaule, V. Theoretical Data on the Multicoordination of Phosphorus and Arsenic. J. Am. Chem. Soc. 1984, 106, 4794-4799.

21. Armentrout, P. B.; Kickel, B. L.“Gas-Phase Thermochemistry of Transition metal Ligand Systems: Reassessment of Values and Periodic Trends," in Organometallic Ion Chemistry, Freiser, B. S. Ed.; Kluwer: Amsterdam, 1996, 1-45. Armentrout, P. B. "Gas-Phase Organometallic Chemistry," in Topics in Organometallic Chemistry Vol. 4, Brown, J. M.; Hofmann, P. Eds.; Springer-Verlag: Berlin, 1999. More, M. B.; Ray, D.; Armentrout, P. B. Intrinsic Affinities of Alkali Cations for 15-Crown-5 and 18-Crown-6: Bond Dissociation Energies of Gas-Phase $\mathrm{M}^{+}$-Crown Ether Complexes J. Am. Chem. Soc. 1999, 121, 417-423.

22. Sunderlin, L. S.“Hypervalent Bonding in Gas-Phase Anions," in Advances in Gas-Phase Ion Chemistry, Vol. 4, Adams, N.; Babcock, L., eds.; JAI Press: Greenwich, CT, 2001.

23. (a) Larson, J. W.; McMahon, T. B. Strong Hydrogen Bonding in Gas-Phase Anions. An Ion Cyclotron Resonance Determination of Fluoride Binding Energetics to Brønsted Acids from Gas-Phase Fluoride Exchange Equilibria Measurements. J. Am. Chem. Soc. 1983, 150, 2944-2950. (b) Larsen, J. W.; McMahon, T. B. Fluoride and Chloride Affinities of Main Group Oxides, Fluorides, Oxofluorides, and Alkyls. Quantitative Scales of Lewis Acidities from Ion Cyclotron Resonance Halide-Exchange Equilibria. J. Am. Chem. Soc. 1985, 107, 766-773. (c) For possible adjustments to the fluoride affinity scale see alsoWenthold, P. G.; Squires, R. R. Bond Dissociation Energies of $\mathrm{F}_{2}^{-}$ and $\mathrm{HF}_{2}^{-}$. A Gas-Phase Experimental and G2 theoretical Study. J. Phys. Chem. 1995, 99, 2002-2005.

24. Haartz, J. C.; McDaniel, D. H. Fluoride Ion Affinity of Some Lewis Acids. J. Am. Chem. Soc. 1973, 95, 8562-8565.

25. Cotton, F. A.; Wilkinson, G.; Murillo, C. A.; Bochmann, M. The Group 15 Elements: P, As, Sb, Bi. In Advanced Inorganic Chemistry; 6th ed. Wiley Interscience: New York, 1999.

26. Chapman, D. M.; Buchanan, A. C., III; Smith, G. P.; Mamantov, G. Bonded vs. Nonbonded Electron Transfers in Molten Salts: Characterization and Rates of Formation of the Radical Cations and Dications of Phenoxazine and Phenothiazine and Behavior of the $\mathrm{M}\left(2,2^{\prime} \text {-bipyridine }\right)_{3}^{2+/ 3+}(\mathrm{M}=\mathrm{Fe}, \mathrm{Ru}, \mathrm{Os})$ Complexes in $\mathrm{SbCl}_{3}$-Rich Media. J. Am. Chem. Soc. 1986, 108, 654-663.
27. Emsley, J.; Hall, D. The Chemistry of Phosphorus. Harper \& Ltd.: London, 1976.

28. Christe, K. O.; Wilson, W. W.; Boatz, J. A. $\mathrm{N}_{5}^{+}$: A Novel Homoleptic Polynitrogen Ion as a High Energy Density Material. Angew. Chem. Int. Ed. Engl. 1999, 38, 2004-2009.

29. McAliffe, C. A.; Levason, W. Studies in Inorganic Chemistry 1: Phosphine, Arsine, Stilbine Complexes of the Transition Elements. Elsevier Scientific Publishing Company: Amsterdam, 1979.

30. Muntean, F.; Armentrout, P. B. Guided Ion Beam Study of Collision-Induced Dissociation Dynamics: Integral and Differential Cross Sections. J. Chem. Phys. 2001, 115, 1213-1228, and refs. therein.

31. (a) Ervin, K. M.; Armentrout, P. B. Translational energy dependence of $\mathrm{Ar}^{+}+\mathrm{XY} 5^{\prime} 76 \mathrm{ArX}^{+}+\mathrm{Y}\left(\mathrm{XY}=\mathrm{H}_{2}, \mathrm{D}_{2}, \mathrm{HD}\right)$ from thermal to $30 \mathrm{eV}$ c.m.. J. Chem. Phys. 1985, 83, 166-189. (b) Rodgers, M. T.; Ervin, K. M.; Armentrout, P. B. Statistical Modeling of Collision-Induced Dissociation Thresholds.. J. Chem. Phys 1997, 106, 4499-4508.

32. Do, K.; Klein, T. P.; Pommerening, C. A.; Sunderlin, L. S. A New Flowing Afterglow-Guided Ion Beam Tandem Mass Spectrometer. Applications to the Thermochemistry of Polyiodide Ions. J. Am. Soc. Mass Spectrom. 1997, 8, 688-696.

33. Nakamoto, K. Infrared and Raman Spectra of Inorganic and Coordination Compounds Part A: Theory and Applications in Inorganic Chemistry; 5th ed. John Wiley \& Sons: New York, 1997.

34. (a)Ahlijah, G. Y.; Goldstein, M. Far-infrared and Raman Spectra of Tetrahalogeno-complexes of Arsenic(III), Antimony(III), and Bismuth(III). J. Chem. Soc. A 1970, 2, 326-330. (b) Ahlijah, G. Y.; Goldstein, M. Vibrational Spectra of Tetrahalogenocomplexes of Antimony(III) and Bismuth(III). Chem. Comm. 1968, 21, 1356-1358.

35. (a) Hay, P. J.; Wadt, W. R. Ab initio effective core potentials for molecular calculations. Potentials for the transition metal atoms Sc to Hg. J. Chem. Phys. 1985, 82, 270-283. (b) Wadt, W. R.; Hay, P. J. Ab initio effective core potentials for molecular calculations. Potentials for main group elements $\mathrm{Na}$ to Bi. J. Chem. Phys. 1985, 82, 284-298. (c) Hay, P. J.; Wadt, W. R. Ab initio effective core potentials for molecular calculations. Potentials for $\mathrm{K}$ to $\mathrm{Au}$ including the outermost core orbitals. J. Chem. Phys. 1985, 82, 299-310.

36. Check, C. E.; Faust, T. O.; Bailey, J. M.; Wright, B. J.; Gilbert, T. M.; Sunderlin, L. S. Addition of Polarization and Diffuse Functions to the LANL2DZ Basis Set for P-Block Elements. J. Phys. Chem. A 2001, 105, 8111-8116.

37. (a) Loh, S. K.; Hales, D. A.; Lian, L.; Armentrout, P. B. Collision-Induced Dissociation of Fen $+(n=2-10)$ with Xe: Ionic and Neutral Iron Binding Energies. J. Chem. Phys. 1989, 90, 5466-5485. (b) Schultz, R. H.; Crellin, K. C.; Armentrout, P. B. Sequential Bond Energies of $\mathrm{Fe}(\mathrm{CO})_{x}^{+}(x=1-5)$ : Systematic Effects on Collision-Induced Dissociation Measurements. J. Am. Chem. Soc. 1991, 113, 8590-8601.

38. Frisch, M. J.; Trucks, G. W.; Schlegel, H. B.; Scuseria, G. E.; Robb, M. A.; Cheeseman, J. R.; Zakrzewski, V. G.; Montgomery, J. A., Jr.; Stratmann, R. E.; Burant, J. C.; Dapprich, S.; Millam, J. M.; Daniels, A. D.; Kudin, K. N.; Strain, M. C.; Farkas, O.; Tomasi, J.; Barone, V.; Cossi, M.; Cammi, R.; Mennucci, B.; Pomelli, C.; Adamo, C.; Clifford, S.; Ochterski, J.; Petersson, G. A.; Ayala, P. Y.; Cui, Q.; Morokuma, K.; Malick, A D.; Rabuck, K. D.; Raghavachari, K.; Foresman, J. B.; Cioslowski, J.; Ortiz, J. V.; Baboul, A. G.; Stefanov, B. B.; Liu, G.; Liashenko, A.; Piskorz, P.; Komaromi, I.; Gomperts, R.; Martin, R. L.; Fox, D. J.; Keith, T.; Al-Laham, M. A.; Peng, C. Y.; Nanayakkara, A.; Challacombe, M.; Gill, P. M. W.; Johnson, B.; Chen, W.; Wong, M. W.; Andres, J. L.; Gonzalez, C.; HeadGordon, M.; Replogle, E. S.; Pople, J. A. Gaussian 98, Revision A.9. Gaussian, Inc.: Pittsburgh, PA, 1998. 
39. Glendening, E. D.; Badenhoop, J. K.; Reed, A. E.; Carpenter, J. E.; Bohmann, J. A.; Morales, C. M.; Weinhold, F. Theoretical Chemistry Institute: University of Wisconsin, Madison, WI, 2001NBO 5.0http://www.chem.wisc.edu/ nbo5.

40. Cioslowski, J.; Mixon, S. T. Rigorous Interpretation of Electronic Wave Functions. 2. Electronic Structures of Selected Phosphorus, Sulfur, and Chlorine Fluorides and Oxides. Inorg. Chem. 1993, 32, 3209-3216.

41. Bader, R. F. W. Atoms in Molecules: A Quantum Theory. Clarendon Press: Oxford, 1990.

42. (a) Cioslowski, J.; Nanayakkara, A.; Challacombe, M. Rapid evaluation of atomic properties with mixed analytical/numerical integration. Chem. Phys. Lett. 1993, 203, 137-142. (b) Cioslowski, J.; Surjan, P. R. An observable-based interpretation of electronic wavefunctions: application to "hypervalent" molecules. J. Mol. Struc. 1992, 255, 9-33. (c) Cioslowski, J.; Stefanov, B. B. Variational determination of the zeroflux surfaces of atoms in molecules. Mol. Phys. 1995, 84, 707-716. (d) Stefanov, B. B.; Cioslowski, J. R. An Efficient Approach to Calculation of Zero-Flux Atomic Surfaces and Generation of Atomic Integration Data. J. Comp. Chem. 1995, 16, 1394-1404. (e) Cioslowski, J. Isopycnic Orbital Transformations and Localization of Natural Orbitals. Int. J. Quant. Chem. Quant. Chem.
Symp. 1990, 24, 15-28. (f) Cioslowski, J.; Mixon, S. T. Covalent Bond Orders in the Topological Theory of Atoms in Molecules. J. Am. Chem. Soc. 1991, 113, 4142-4145. (g) Cioslowski, J. An Efficient Evaluation of Atomic Properties Using a Vectorized Numerical Integration with Dynamic Thresholding. Chem. Phys. Lett. 1992, 194, 73-78. (h) Cioslowski, J. A New Robust Algorithm for Fully Automated Determination of Attractor Interaction Lines in Molecules. Chem. Phys. Lett. 1994, 219, 151-154.

43. Heats of formation for $\mathrm{P}$ and $\mathrm{Cl}$ from: Afeefy, H. Y.; Liebman, J. F.; Stein, S. E. "Neutral Thermochemical Data" in NIST Chemistry WebBook, NIST Standard Reference Database Number 69, Linstrom, P. J.; Mallard, W. G., Eds., July 2001, National Institute of Standards and Technology, Gaithersburg MD, 20899 (http://webbook.nist.gov). Other data from: Woods, T. L.; Garrels, R. M. Thermodynamic Values at Low Temperatures for Natural Inorganic Materials: An Uncritical Summary. Oxford University Press: Oxford, 1987.

44. Mingos, D. M. P. Essential Trends in Inorganic Chemistry. Oxford University Press: Oxford, 1998.

45. Gailbreath, B. D.; Pommerening, C. A.; Bachrach, S. M.; Sunderlin, L. S. Potential Energy Surface of $\mathrm{SCl}_{3}^{-}$. J. Phys. Chem. A 2000, 104, 2958-2961. 